Sharif University of Technology
Scientia Iranica
SCIENTIA
I RAN I CA

\title{
The effect of current density on microstructural homogeneity, hardness, fracture toughness and electrochemical behavior of electrodeposited $\mathrm{Cu}-0.5 \mathrm{Co} / \mathrm{WC}$ nano-composite coating
}

\author{
Sh. Khaleghpanah*, P. Abachi and A. Dolati \\ Department of Material Science and Engineering, Sharif University of Technology, Tehran, P.O. Box 11155-9466, Iran.
}

Received 8 August 2016; received in revised form 15 January 2017; accepted 6 March 2017

\section{KEYWORDS \\ Nano-composite coating; \\ Electrodeposition; \\ Homogeneity; \\ Hardness; \\ Corrosion; \\ Resistance.}

\begin{abstract}
The Cu-0.5Co/WC nano-composite coating was synthesized on CP-copper substrate using Direct Current (DC) electrodeposition method. In this work, it was tried to increase the hardness of surface without considerable degradation of copper's particular physical properties such as electrical conductivity. The effect of current density on microstructural homogeneity, hardness, fracture toughness, and electrochemical behavior of coating was investigated. The copper plates with the purity of $99.99 \%$ were used as electrodes. The electrolyte consists of tungsten carbide particles (30 g/l), copper sulfate (200 g/1), sulfuric acid (50 g/1), cobalt sulfate (50 g/1), and Sodium Dodecyl Sulfate (SDS) $(0.3 \mathrm{~g} /(\mathrm{g}$ of $\mathrm{WC}))$ as surfactant. The particle size of tungsten carbide powder was in the range of 40-70 $\mathrm{nm}$. The distribution of tungsten carbide particles in coating was studied using FESEM. Micro-hardness measurement was performed in Vickers scale. The fracture toughness of coating was determined by Vickers indentation test. The corrosion resistance of the electrodeposited $\mathrm{Cu}-\mathrm{Co}$ and $\mathrm{Cu}-\mathrm{Co} / \mathrm{WC}$ nano-composite coatings was evaluated by polarization studies. Referring to the results, the use of optimum current density value $\left(60 \mathrm{~mA} / \mathrm{cm}^{2}\right)$ during the electrodeposition process improves hardness and corrosion resistance of nano-composite coating. Additionally, $\mathrm{Cu}-\mathrm{Co} / \mathrm{WC}$ composite coating shows more corrosion resistance than the unreinforced one.
\end{abstract}

(C) 2017 Sharif University of Technology. All rights reserved.

\section{Introduction}

Improving the performance and service life of a product by modifying its surface properties has remained a research topic for long. Nanostructured composites deposited by the method of electrochemical deposition

\footnotetext{
*. Corresponding author. Tel.: +982166165217 E-mail addresses: shila_khaleghpanah@yahoo.com (Sh. Khaleghpanah); abachi@sharif.edu (P. Abachi); abachi@sharif.edu (A. Dolati)
}

(electrodeposition) have been extensively studied during the last decade due to their interesting electronic, magnetic, electrochemical and optical properties and potential use as catalytic and electrode materials in various devices [1]. Electrochemical deposition has a widespread use in nanotechnology since it can be used to fill three-dimensional features at room temperature with good control of thickness and morphology [1]. During the last few decades, researchers have attempted to improve the properties through electrocodeposition of hard particles such as $\mathrm{WC}, \mathrm{Al}_{2} \mathrm{O}_{3}, \mathrm{SiC}$, and $\mathrm{Si}_{3} \mathrm{~N}_{4}[2-5]$ in various metal matrix materials such as $\mathrm{Ni}$ and $\mathrm{Cu}[2,3]$. The copper electroplates are widely 
used in engineering applications due to their high electrical and thermal conductivity, proper ductility, and required corrosion resistance. Nevertheless, these specimens show low hardness and wear resistance. In order to improve or modify the properties of copper coatings, ceramic particles [3] were incorporated into copper. The properties of nano-composites are dependent on both uniform distribution and the amount of incorporated particles within the matrix. The incorporation of nano-sized particles is influenced by various process parameters, including particle concentration, shape, size, bath composition, additives, $\mathrm{pH}$, and current density. Researchers suggested that the applied current density, particle type, particle concentration, and bath agitation are the main influencing factors in the co-deposition process $[5,6]$. The aim of the present work is the production of $\mathrm{Cu}-\mathrm{Co} / \mathrm{WC}$ nanocomposite coating using copper sulfate bath and also specification of optimum processing condition. The influence of current density on the tungsten carbide particles distribution, some mechanical properties, and corrosion behavior of coating was analyzed. The present $\mathrm{Cu}-\mathrm{Co} / \mathrm{WC}$ nano-composite coatings showed a significant improvement in hardness, fracture toughness, and corrosion resistance as compared to the previous composite coatings [2-4]. These improvements mainly depended on the nature and content of the tungsten carbide co-deposited particles, as well as on their distribution in the metallic matrix.

\section{Materials and method}

$\mathrm{Cu}-0.5 \mathrm{Co} / \mathrm{WC}$ nano-composite coating was coelectrodeposited using the electrolyte containing copper sulfate $(200 \mathrm{~g} / \mathrm{l})$, sulfuric acid $(50 \mathrm{~g} / \mathrm{l})$, cobalt sulfate $(50 \mathrm{~g} / \mathrm{l})$, and Sodium Dodecyl Sulfate (SDS) $(0.3 \mathrm{~g} /(\mathrm{g}$ of $\mathrm{WC}))$ and suspended nano-sized tungsten carbide particles $(30 \mathrm{~g} / \mathrm{l})$ at temperature $50^{\circ} \mathrm{C}$ and $\mathrm{pH}$ of 1.25 . The tungsten carbide powder of $40-70 \mathrm{~nm}$ size was maintained in suspension by magnetic stirring at $600 \mathrm{rpm}$. Direct current was used for electrodeposition. The current density varied in the range of $20-80 \mathrm{~mA} / \mathrm{cm}^{2}$. The copper plate with the thickness of $0.5 \mathrm{~mm}$, and purity of $99.99 \%$ was selected as cathode (substrate). The cathode exposure surface area was considered as $1 \mathrm{~cm}^{2}$. Prior to electrodeposition, the substrates were mechanically polished. The resultant coating thickness was equal to $60 \mu \mathrm{m}$ after $30 \mathrm{~min}$. The distribution of tungsten carbide particles in coating was studied using FE-SEM (Model of Mira 3-XMU). Vickers micro-hardness tests were performed using a Wolpert-MC110 instrument at three different areas at load of $30 \mathrm{~g}$ for a duration of $15 \mathrm{~s}$. The coating toughness was determined by Vickers indentations test. The applied load was in the range of $30-50 \mathrm{~kg}$, and the following equation [7] was used for the calculation:

$$
K_{c}=0.0889\left(\frac{H_{\nu} \cdot P}{\sum_{i=1}^{4} c_{i}}\right)^{1 / 2},
$$

where $K_{C}, H_{V}, P$, and $c$ are fracture toughness, hardness, indentation load, and crack length from the centre of indentation impression, respectively. The corrosion resistance of $\mathrm{Cu}-\mathrm{Co}$ and $\mathrm{Cu}-\mathrm{Co} / \mathrm{WC}$ nanocomposite coatings was evaluated by electrochemical measurements in $3.5 \% \mathrm{NaCl}$ solutions at scan rate of $0.5 \mathrm{~V}$. The Auto Lab PG STAT $302 \mathrm{~N}$ instrument was used for plotting the polarization curves. Consequent results were analyzed by Eco Chemie Nova 1.6 software.

\section{Results and discussion}

Figure 1(a)-(d) reveals the distribution of tungsten carbide particles on the surface of $\mathrm{Cu}-\mathrm{Co} / \mathrm{WC}$ nanocomposite coating prepared by applying various current densities. In Figure 1(c), approximate homogenous distribution of tungsten carbide on the coating surface at optimum current density $\left(60 \mathrm{~mA} / \mathrm{cm}^{2}\right)$ can be seen. Figure 2 shows the Energy dispersive X-Ray spectroscopy) (EDS) (spectra of electrodeposited $\mathrm{Cu}-$ $\mathrm{Co} / \mathrm{WC}$ nano-composite coatings at different current densities, confirming the presence of copper, tungsten, and cobalt elementals in the composites. The difference in intensity of $\mathrm{W}$ peaks is noticeable. The effect of current density on co-deposited tungsten carbide particles content is shown in Figure 3 using results of EDS analysis. It is clear that the content of the co-deposited tungsten carbide nano-particles is enhanced initially with the current density increase and is reached to a maximum value at $60 \mathrm{~mA} / \mathrm{cm}^{2}$. Beyond this current density value, the amount of co-deposited tungsten carbide particles decreases. Before reaching the maximum, the increment can be attributed to the increased tendency for absorbed particles to be attached to the cathode surface, which is consistent with Guglielmi's model [8]. When current density is higher than 60 $\mathrm{mA} / \mathrm{cm}^{2}$, the decreasing trend can be explained by the fact that an increase in current density results in more rapid deposition of the metal matrix and fewer ceramic particles could be embedded in the coating. A typical XRD pattern of the as-synthesized $\mathrm{Cu}-\mathrm{Co} / \mathrm{WC}$ nanocomposite coating at optimum current density is shown in Figure 4. The XRD pattern shows diffraction peaks of $\mathrm{Cu}, \mathrm{Co}$, and $\mathrm{WC}$. The appearance of the intense diffraction peak corresponding to $\mathrm{Cu}$ in coating pattern is due to the usage of copper as a substrate in the present study.

The micro-hardness values of $\mathrm{Cu}-\mathrm{Co} / \mathrm{WC}$ nanocomposite coatings produced in different conditions are shown in Table 1. It reveals that the hardness enhances by increasing the current density from 20 


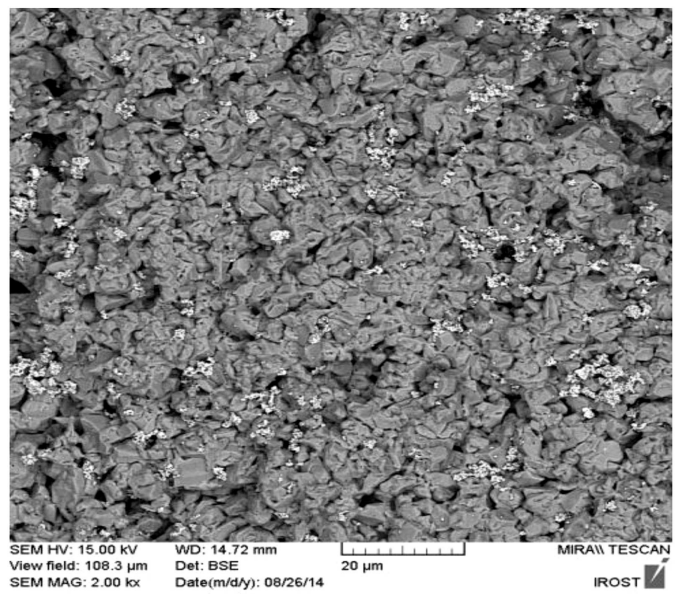

(a)

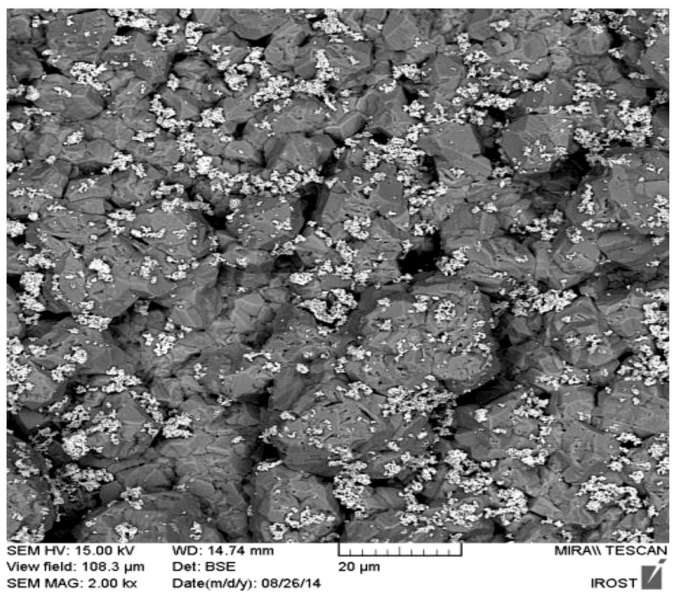

(c)

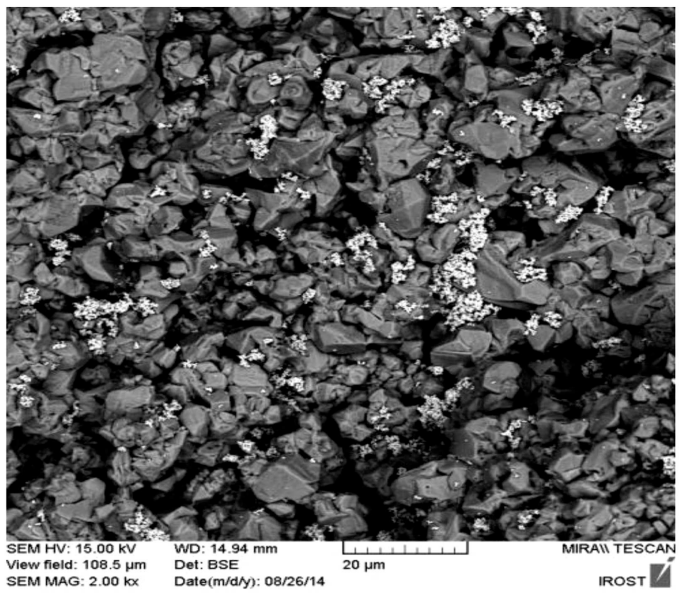

(b)

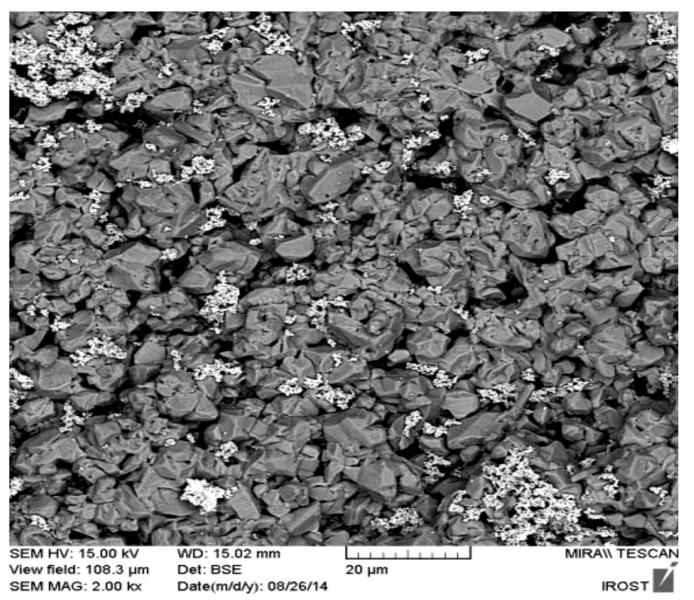

(d)

Figure 1. FESEM images showing the distribution of tungsten carbide particles on the surface of $\mathrm{Cu}-\mathrm{Co} / \mathrm{WC}$ nano-composite coating produced using a current density of: (a) 20 (b) 40 (c) 60 and (d) $80 \mathrm{~mA} / \mathrm{cm}^{2}$ (white and gray regions showing tungsten carbide particles and $\mathrm{Cu}-\mathrm{Co}$ matrix, respectively.)

Table 1. The effect of current densities on micro-hardness of the $\mathrm{Cu}-\mathrm{Cu}-\mathrm{Co} / \mathrm{WC}$ nano-composite coatings.

\begin{tabular}{lcc}
\hline Coating & $\begin{array}{c}\text { Cathodic } \\
\text { applied current } \\
\text { density } \\
\left(\mathbf{m A} / \mathbf{c m}^{\mathbf{2}}\right)\end{array}$ & $\begin{array}{c}\text { Micro- } \\
\text { hardness (HV) }\end{array}$ \\
\hline $\mathrm{Cu}-\mathrm{Co} / \mathrm{WC}$ & 20 & $415 \pm 50$ \\
$\mathrm{Cu}-\mathrm{Co} / \mathrm{WC}$ & 40 & $422 \pm 26$ \\
$\mathrm{Cu}-\mathrm{Co} / \mathrm{WC}$ & 60 & $530 \pm 28$ \\
$\mathrm{Cu}-\mathrm{Co} / \mathrm{WC}$ & 80 & $512 \pm 27$ \\
\hline
\end{tabular}

to $60 \mathrm{~mA} / \mathrm{cm}^{2}$ and decreases by further increase of the current density to $80 \mathrm{~mA} / \mathrm{cm}^{2}$. This is due to maximum incorporation of hard tungsten carbide nano particles at current density of $60 \mathrm{~mA} / \mathrm{cm}^{2}$. The hardness improvement from $110 \mathrm{HV}$ (pure $\mathrm{Cu}$ ) to $530 \mathrm{HV}(\mathrm{Cu}-\mathrm{Co} / \mathrm{WC}))$ is comparable with the results reported by Tsyntsaru et al. [8]. It is also observed that $\mathrm{Cu}-\mathrm{Co} / \mathrm{WC}$ nano-composite coating has a much higher micro-hardness value $(530 \mathrm{HV})$ than that of the $\mathrm{Cu} / \mathrm{WC}$ nano-composite coating [9].

The presence of tungsten carbide nano particles in electrodeposited coating reduces the fracture toughness of copper. It seems that the indentation fracture toughness of coatings has been affected by current density and tungsten carbide content of coating (Figure 5). The fracture toughness of $\mathrm{Cu}-\mathrm{Co} / \mathrm{WC}$ nanocomposite coating is more than that in WC-Co cemented carbide [10]. However, the applicability of the indentation models for nano-composite coatings with low amounts of reinforcing particles should be further investigated. The corrosion potential $\left(E_{\text {corr }}\right)$ and current $\left(i_{\text {corr }}\right)$ of $\mathrm{Cu}-\mathrm{Co}$ and $\mathrm{Cu}-\mathrm{Co} / \mathrm{WC}$ nanocomposite coatings were determined from the Tafel polarization curves (Figure 6). The related values are given in Table 2. It can be concluded that the corrosion currents $\left(i_{\text {corr }}\right)$ of all $\mathrm{Cu}-\mathrm{Co} / \mathrm{WC}$ nanocomposite coatings decrease compared to that of electrodeposited $\mathrm{Cu}-\mathrm{Co}$. In corrosion potential of $\mathrm{Cu}-\mathrm{Co} / \mathrm{WC}$ nano-composites, 


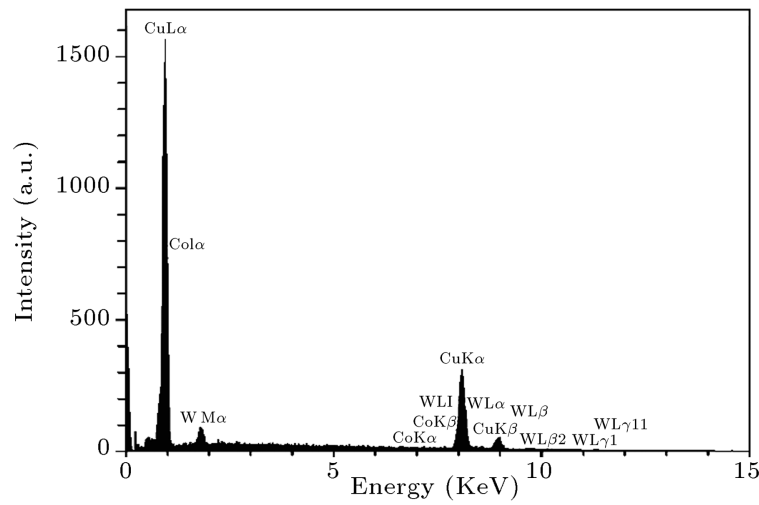

(a)

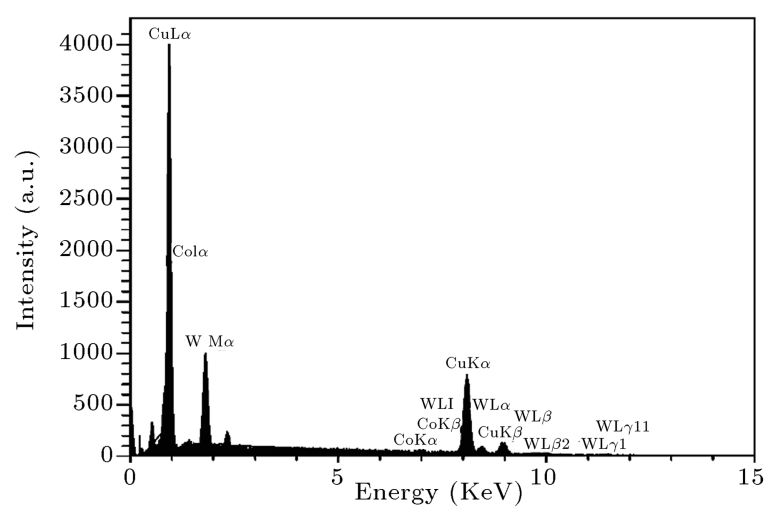

(c)

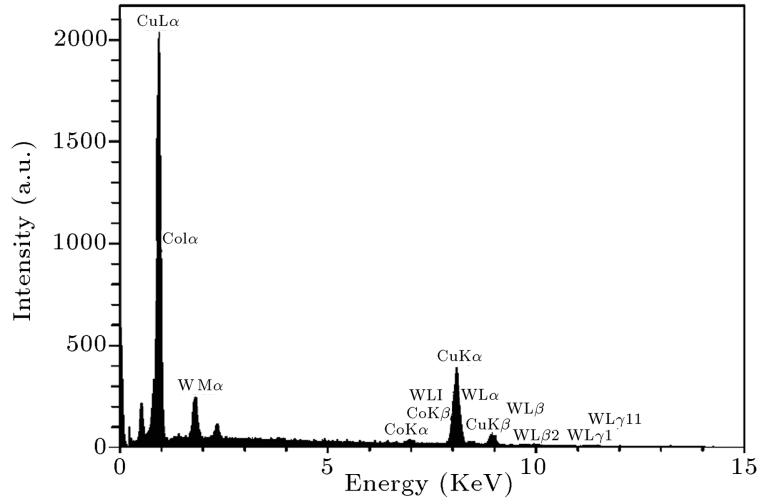

(b)

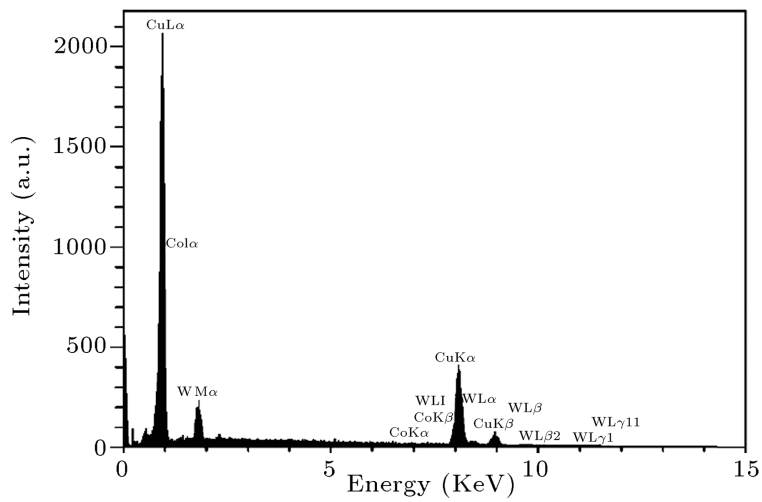

(d)

Figure 2. EDS spectra of Cu-Co/WC nano-composite coatings at different current densities: (a) 20, (b) 40, (c) 60, and (d) $80 \mathrm{~mA} / \mathrm{cm}^{2}$.

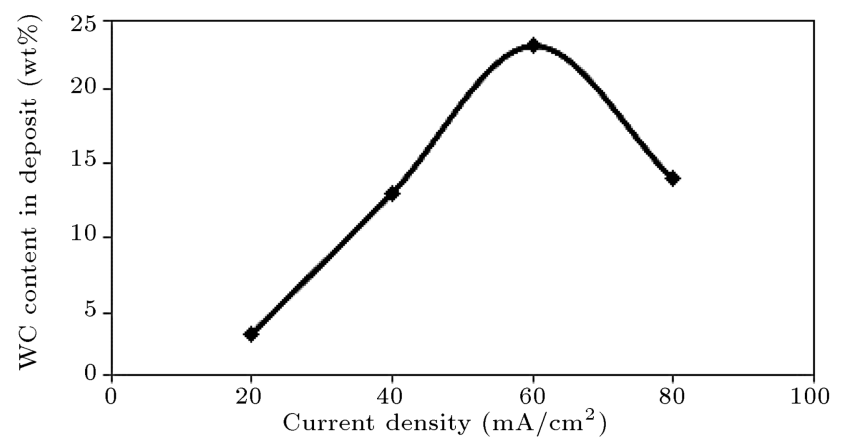

Figure 3. The weight percentage of co-deposited WC particles versus applied current density during processing of $\mathrm{Cu}-\mathrm{C} 0 / \mathrm{WC}$ nano-composite coating, according to the results of EDS analysis.

a negative shift can be seen, confirming the cathodic protective nature of the coatings. This observation is opposed to the corrosion investigation results of pulse electrodeposited Ni-W-SiC coating [4], but similar to those reported for $\mathrm{Ni}-\mathrm{W} / \mathrm{ZrO}_{2}$ nano-composite coatings [11] and WC-Co/Fe nano-composite coatings [12].

In Table 3, the results of some reported studies on copper and cobalt matrices are summarized concisely. In spite of differences in processing routes and parameters such as particle size and content, there is a convergence in the properties of the produced composites.

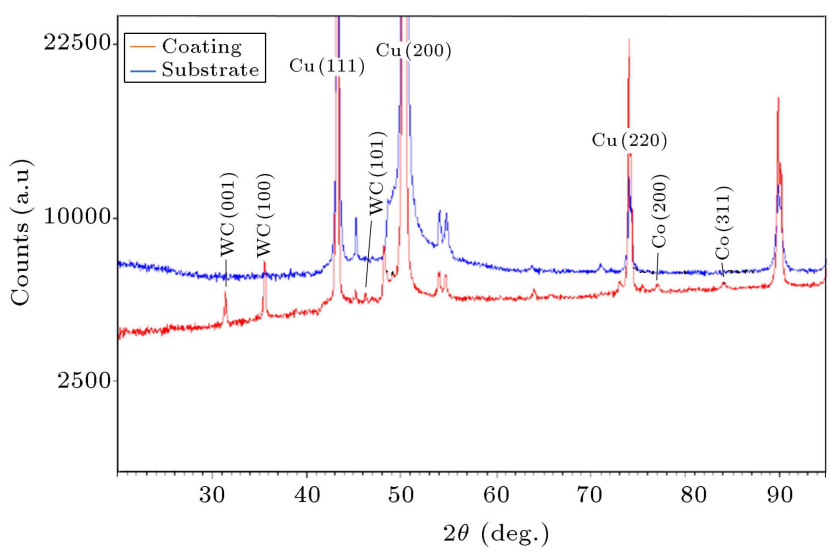

Figure 4. The XRD patterns of copper substrate and $\mathrm{Cu}-\mathrm{Co} / \mathrm{WC}$ nano-composite coating.

Table 2. The Corrosion potential and current of $\mathrm{Cu}-\mathrm{Co}$, $\mathrm{Cu}-\mathrm{Co} / \mathrm{WC}$ nano-composite coatings.

\begin{tabular}{|c|c|c|c|}
\hline & Cathodic & Corrosion & Corrosion \\
\hline Coating & $\begin{array}{l}\text { current density } \\
\left(\mathrm{mA} / \mathrm{cm}^{2}\right)\end{array}$ & $\begin{array}{c}\text { current density } \\
\left(\times 10^{-5} \mathrm{~A}\right)\end{array}$ & $\begin{array}{c}\text { potential } \\
(\mathrm{V})\end{array}$ \\
\hline $\mathrm{Cu}-0.5 \mathrm{Co}$ & 60 & 1.18 & -0.10856 \\
\hline $\mathrm{Cu}-\mathrm{Co} / \mathrm{WC}$ & 20 & 2.1909 & -0.2623 \\
\hline $\mathrm{Cu}-\mathrm{Co} / \mathrm{WC}$ & 40 & 1.1124 & -0.2823 \\
\hline $\mathrm{Cu}-\mathrm{Co} / \mathrm{WC}$ & 60 & 0.052 & -0.38115 \\
\hline $\mathrm{Cu}-\mathrm{Co} / \mathrm{WC}$ & 80 & 0.31 & -0.3483 \\
\hline
\end{tabular}


Table 3. A summary of some reported works' results for copper- and cobalt-matrix reinforced with tungsten carbide particles.

\begin{tabular}{|c|c|c|c|c|c|}
\hline Matrix & Particles & Processing route & Purpose of work & Remarks & Ref. \\
\hline $\mathrm{Cu}, \mathrm{Co}$ & WC & $\begin{array}{l}\text { Co-electro- } \\
\text { deposition } \\
\text { of nano-sized } \\
\text { tungsten } \\
\text { carbide particles } \\
\text { and copper-cobalt } \\
\text { matrix. }\end{array}$ & $\begin{array}{l}\text { To evaluate the influence } \\
\text { of current density on the } \\
\text { tungsten carbide particles } \\
\text { distribution as well as } \\
\text { hardness, indentation fracture } \\
\text { toughness \& electrochemical } \\
\text { behavior of coating. }\end{array}$ & $\begin{array}{l}\text { The use of proper surfactant and } \\
\text { current density stabilizes WC } \\
\text { nano-particles suspension, promotes } \\
\text { the nanoparticles incorporation in the } \\
\text { matrix, and consequently improves the } \\
\text { microstructural homogeneity, hardness } \\
\text { and corrosion resistance of } \mathrm{Cu}-0.5 \mathrm{Co} / \mathrm{WC} \\
\text { nano-composite coating. The Cu-Co/WC } \\
\text { nano-composite coating shows higher } \\
\text { hardness, but lower indentation fracture } \\
\text { toughness compared with the tungsten } \\
\text { carbide free coating. }\end{array}$ & $\begin{array}{c}\text { Present } \\
\text { work }\end{array}$ \\
\hline $\mathrm{Cu}$ & WC & $\begin{array}{l}\text { Co-electrodeposition } \\
\text { of micrometer-sized } \\
\text { tungsten carbide } \\
\text { (WC) particles and } \\
\text { copper matrix. }\end{array}$ & $\begin{array}{l}\text { To investigated the } \\
\text { structure, morphology, } \\
\text { surface roughness } \\
\text { as well as interfacial } \\
\text { phenomena (wetting } \\
\text { ability and wear) }\end{array}$ & $\begin{array}{l}\text { The tungsten carbide particles } \\
\text { have a hardening effect on the } \\
\text { metal matrix. The wear resistance } \\
\text { of a dispersion hardened Cu-WC } \\
\text { composite coating is slightly higher } \\
\text { than that of pure copper. }\end{array}$ & {$[9]$} \\
\hline $\mathrm{Co}$ & $\mathrm{WC}$ & $\begin{array}{l}\text { High pressure } \\
\text { melt infiltration }\end{array}$ & $\begin{array}{l}\text { To realize the optimal } \\
\text { distribution with WC \& } \\
\text { Co liquid to obtain better } \\
\text { properties and performances. }\end{array}$ & $\begin{array}{l}\text { The results of Vickers hardness } \\
\text { tests, fracture toughness tests } \\
\text { and cutting performance tests } \\
\text { show that well-sintered WC-Co } \\
\text { composites exhibit a prominent } \\
\text { combination of high hardness \& } \\
\text { large fracture toughness value. }\end{array}$ & {$[10]$} \\
\hline $\mathrm{Cu}$ & $\mathrm{WC}, \mathrm{Co}$ & Hot pressing & $\begin{array}{l}\text { To evaluate the effects } \\
\text { of WC and Co particles } \\
\text { content and size on the } \\
\text { wear and corrosion } \\
\text { properties of the } \\
\text { copper composites. }\end{array}$ & $\begin{array}{l}\text { The results show that the hardness, } \\
\text { wear resistance and static corrosion } \\
\text { weight loss of } \mathrm{Cu} / \mathrm{WC} \text { composites } \\
\text { increase with a decrease of WC size } \\
\text { or with an increase of WC content. } \\
\text { The Cu/WC/Co composites show a } \\
\text { much lower } E_{\text {corr }} \text { and significantly } \\
\text { more passivity than Cu/WC composites. } \\
\text { The Cu/WC/Co composites exhibit } \\
\text { excellent wear corrosion resistance. }\end{array}$ & {$[13]$} \\
\hline $\mathrm{Cu}$ & WC, Co & Hot pressing & $\begin{array}{l}\text { To examine the influence } \\
\text { of particulate WC \& } \\
\text { Co particles on wear, } \\
\text { corrosion, and their } \\
\text { synergistic effect on } \\
\text { the properties of } \\
\mathrm{Cu} / \mathrm{WC} / \mathrm{Co} \mathrm{MMCs} \text {. }\end{array}$ & $\begin{array}{l}\text { It was observed that the average } \\
\text { electrical resistivity of the composites } \\
\text { increases about } 1.6 \% \text { at } 8 \mathrm{wt} . \% \mathrm{WC} \\
\text { particles. The hardness of the } \\
\text { composites was found to increase } \\
\text { with increased reinforcement content. }\end{array}$ & {$[14]$} \\
\hline
\end{tabular}




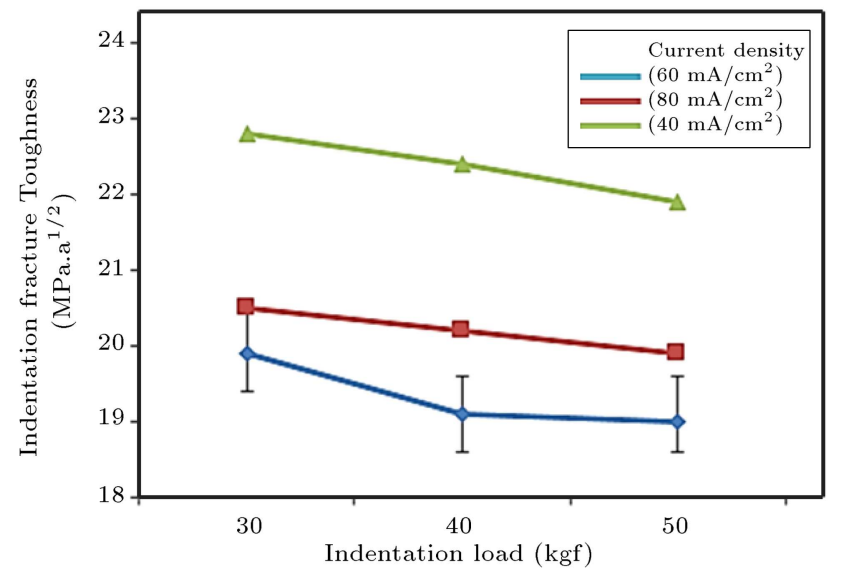

Figure 5. The indentation fracture toughness of $\mathrm{Cu}-\mathrm{Co} / \mathrm{WC}$ as a function of applied indentation loads.

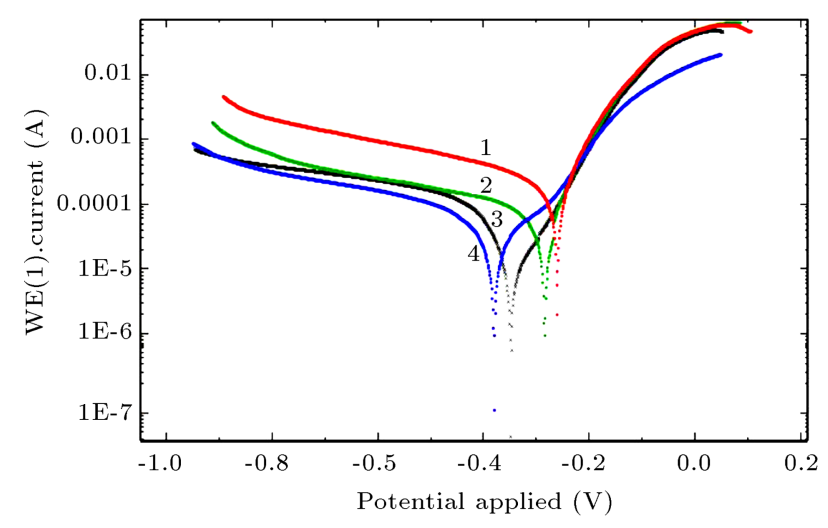

Figure 6. Polarization curves of $\mathrm{Cu}-\mathrm{Co} / \mathrm{WC}$ coating electrodeposited at current density of $20,40,80$, and 60 $\mathrm{mA} / \mathrm{cm}^{2}$ designated as $1,2,3$, and 4 , correspondingly.

The effects of other micro- and nano-sized particles incorporation on mechanical, physical, and chemical properties of electrodeposited copper matrix are to some extent similar to those given in Table $3[15,16]$. Since the reinforcement type, bath and deposition variables, and characteristics of resulted composites are not alike, the findings are not completely compatible.

\section{Conclusions}

The effect of current density on microstructural homogeneity, hardness, fracture toughness, and corrosion resistance of $\mathrm{Cu}-0.5 \mathrm{Co} / \mathrm{WC}$ nano-composite coating was successfully investigated. The use of optimum current density value $\left(60 \mathrm{~mA} / \mathrm{cm}^{2}\right)$ during the electrodeposition process improves hardness and corrosion resistance of nano-composite coating. Nevertheless, the indentation fracture toughness degrades by the incorporation of tungsten carbides particles, especially as the particles' content increases at current density of $60 \mathrm{~mA} / \mathrm{cm}^{2}$.

\section{References}

1. Jiang, M., Ma, C., Xia, F. and Zhang, Y. "Application of artificial neural networks to predict the hardness of Ni-TiNnanocoatings fabricated by pulse electrodeposition", Surface and Coatings Technology, 286, pp. 191-1966 (2016).

2. Gupta, R.N., Das, A.K. and Henal, S. "Pulse electrocodeposited Ni-WC composite coating", Materials and Manufacturing Processes, 31(1), pp. 42-47 (2016).

3. Tey, E., Hashim, M. and Ismail, I. "Characterization of $\mathrm{Cu}-\mathrm{Al}_{2} \mathrm{O}_{3}$ and $\mathrm{Ni}-\mathrm{Al}_{2} \mathrm{O}_{3}$ nanocomposites electrodeposited on copper substrate", Materials Science Forum, 846, pp. 471-478 (2016).

4. Singh, S., Sribalaji, M., Wasekar, N.P., Joshi, S., Sundararajan, G., Singh, R. and Keshri, A.K. "Microstructural, phase evolution and corrosion properties of silicon carbide reinforced pulse electrodeposited nickel-tungsten composite coatings", Applied Surface Science, 364, pp. 264-272 (2016).

5. Tripathi, M.K. and Singh, V.B. "Microstructure and properties of $\mathrm{Si}_{3} \mathrm{~N}_{4}$ and TiN nano-particles reinforced electrodeposited functional $\mathrm{Ni}-\mathrm{Fe}$ matrix nanocomposite", Electrochemical Society, 163(8), pp. 453-461 (2016).

6. Jiudong, X., Gang, Y., Bonian, H. and Zhang, J. "Preparation of copper coated tungsten powders by intermittent electrodeposition", Powder Technology, 264, pp. 561-569 (2014).

7. Soleimanpour, A., Abachi, P. and Simchi, A. "Microstructure and mechanical properties of WC-10Co cemented carbide containing $\mathrm{VC}$ or $(\mathrm{Ta}, \mathrm{Nb}) \mathrm{C}$ and fracture toughness evaluation using different models", Int. J. of Refractory Metals and Hard Materials, 31, pp. 141-146 (2012).

8. Tsyntsarua, N., Belevskyb, S. and Cesiulisc, H. "Cu/Co-W nanolayers electrodeposited from Single bath and investigations of their nanohardness", Surface Engineering and Applied Electrochemistry, 48(5), pp. 418-425 (2012).

9. Medeliene, V., Kosenko, A. "Structural and functional properties of electrodeposited copper metal matrix composite coating with inclusions of WC", Materials Science, 14(1) pp. 29-33 (2008).

10. Fan, X., He, D., Wang, P., Li, D., Liu, Y., Ma, D., Du, Y., Gao, S. and Kou, Z. "High pressure infiltration sintering behavior of WC-Co alloys", High Pressure Research, pp. 1-10 (2016).

11. Beltowska-Lehman, E., Indyka, P., Bigos, A., Szczerba, M.J., Guspiel, J., Koscielny, H. and Kot, M. "Effect of current density on properties of NiW nanocomposite coatings reinforced with zirconia particles", Materials Chemistry and Physics, 173, pp. 524-533 (2016). 
12. Wang, G., Xing, C., Tao, F., Ding, P., and Zhongjia, $\mathrm{H}$. "Enhancement in the corrosion resistance of WC coatings by adding a Fe-based alloy in simulated seawater", Surface and Coatings Technology, 305, pp. 62-66 (2016).

13. Wu, T.F., Lee, S.L., Chen, M.H., Li, Z.G. and Lin, J.C. "Effects of tungsten carbide and cobalt particles on corrosion and wear behaviour of copper matrix composite", Materials Science and Technology, 21(3), pp. 295-304 (2005).

14. Girish, B.M., Basawaraj, B.R., Satish, B.M. and Somashekar, D.R. "Electrical resistivity and mechanical properties of tungsten carbide reinforced copper alloy composites", Int. J. of Composite Materials, 2 (3), pp. 37-42 (2012).

15. Li, H., Wan, Y., Liang, H., Li, X., Huang, Y. and $\mathrm{He}, \mathrm{F}$. "Composite electroplating of $\mathrm{Cu}-\mathrm{SiO}_{2}$ nano particles on carbon fiber reinforced epoxy composites", Applied Surface Science, 256(5), pp. 1614-1616 (2009).

16. Zamblau, I., Varvara, S. and Muresan, L.M. "Corrosion behavior of $\mathrm{Cu}-\mathrm{SiO}_{2}$ nanocomposite coatings obtained by electrodeposition in the presence of cetyl trimethyl ammonium bromide", J. of Materials Science, 46(20), pp. 6484-6490 (2011).

17. Gan, Y., Lee, D., Chen, X., Kysar, J.W. "Structure and properties of electrocodeposited $\mathrm{Cu}-\mathrm{Al}_{2} \mathrm{O}_{3}$ nanocomposite thin films", J. of Engineering Materials Technology, 127, pp. 451-456 (2005).

\section{Biographies}

Shila Khaleghpanah received her MSc degree in Materials Science \& Engineering at Sharif University of Technology (SUT) Tehran, Iran. Her research interests include surface engineering and coatings, processing and mechanics of composite materials, electrochemistry, nanomaterials processing, characterization and biomaterials, and biomedical applications, which include biomedical implants, tissue engineering, etc. She has worked on several projects and received further training in coating, electrochemical, nanostructured and biomaterials. Furthermore, she has published a few papers and conference papers as a result of this line of work.

Abolghasem Dolati is a Professor at Sharif University of Technology at the Department of Materials Science and Engineering, Tehran, Iran. He teaches metals corrosion and oxidation, electrochemical thermodynamics, advanced electrochemistry, corrosion inhibitors, advanced nanomaterials, gas-phase oxidation, principles of electrochemistry and corrosion and instrumental methods in electrochemistry. His research interests focus on electrodeposition of thin film; composites and nanomaterials; mechanisms of metal and alloy electrodeposition; modeling and simulation of electrodeposition; and Corrosion \& protection of materials.

Parvin Abachi is an Associate Professor of Materials Science and Engineering at Sharif University of Technology, Tehran, Iran, where he teaches powder metallurgy principles, composites and physical metallurgy I and metallography lab. Her research interests include processing and mechanics of composite materials, Processing of materials via powder metallurgical route and production of MMNC's (in-situ, ex-situ). 